\title{
Factors causing variability in formation of coronary collaterals during coronary artery disease
}

\author{
S. Balakrishnan ${ }^{1}$, B. Senthil Kumar ${ }^{2}$ \\ ${ }^{1}$ Department of Anatomy, Government Medical College, Institute of Integrated Medical Sciences, Palakkad, Kerala, India \\ 2Department of Anatomy Vinayaka Mission's Kirupananda Variyar Medical College, Vinayaka Missions Research \\ Foundation (DU), Salem, Tamilnadu, India
}

[Received: 8 August 2021; Accepted: 11 October 2021; Early publication date: 26 October 2021]

Coronary artery disease (CAD) is one of the major causes of death worldwide. CAD is narrowing of coronary arteries that prevents adequate blood supply to the heart muscle and results in acute coronary syndrome which includes unstable angina and myocardial infarction. The only remedy for it is to restore the perfusion through percutaneous intervention and grafting which may sometime cause reperfusion injury and other complications. Coronary collaterals are small inter-arterial connections that act as natural bypass which provide blood flow to the vascular territory, when the artery supplying to it gets obstructed. Acute collateral recruitment can occurs as a remedy for these adverse cardiac events. Various methods of therapies considered for the promotion and sustenance of functional coronary collaterals. The determinants of human coronary collaterals give clear evidence for prognosis in CAD and a new insight for further therapeutic promotion of coronary collaterals. This review mainly focuses on various studies done on coronary collaterals and the effect of various demographic, morphological and cardiovascular risk factors on the formation of coronary collaterals during obstructive CAD. Many studies have proven that various independent variables such as morphology of coronary artery, location of the lesion, duration of the occlusion, coronary dominance, biochemical factors, and cardiac risk factors, such as diabetes, hypertension, also affect collateral formation. The current update review gives a holistic view on coronary collaterals and findings of various authors on the effect of these independent variables on collateral formation. (Folia Morphol 2022; 81, 4: 815-824)

Key words: angiogenesis, arteriogenesis, percutaneous intervention, collateralisation, vascular endothelial growth factors, shear stress, oestrogen receptors

\section{INTRODUCTION}

Heart diseases are a major cause of death in India. One fifth of heart disease cases are caused by complete or partial obstruction of the coronary arteries. Cardiovascular disease was a major cause of death worldwide in
2013 [8]. Reperfusion is the only method of restoration of blood flow to the area at risk, but it can cause damage to the tissue - a phenomenon called "reperfusion injury" - and also cause additional episodes of myocardial infarction, stroke and even death in elderly patients [27].

Address for correspondence: Ass. Prof. S. Balakrishnan, Chaithanya, Hill View Nagar, Pudupariyaram, Palakkad, Kerala, India-678731, tel: 09645003237, e-mail: sheejabkrishna@gmail.com

This article is available in open access under Creative Common Attribution-Non-Commercial-No Derivatives 4.0 International (CC BY-NC-ND 4.0) license, allowing to download articles and share them with others as long as they credit the authors and the publisher, but without permission to change them in any way or use them commercially. 
Coronary collaterals serve as alternative conduits of blood flow during obstructive coronary heart disease [3]. The existence of coronary collaterals during coronary artery disease (CAD) was first documented in 2003 [62]. Coronary collateral circulation is an adaptive mechanism of the heart against ischaemia which aids in maintaining tissue perfusion. Collaterals are inter-arterial connections that maintain the blood flow so that the organ which is supplied by the artery is protected from ischaemia [74].

Based on studies done by Baroldi et al. [7] on angiograms and post mortem specimens it was found that coronary arteries are not end arteries but are interconnected with an arteriolar network that expands during coronary occlusion. Zoll et al. [79] showed in his studies on post mortem specimens that the grades of anastomosis between the coronary arterioles depends on the severity of coronary stenosis and it was found to be $9 \%$ in normal heart and $95 \%$ in complete stenosis. Habib et al. [25] showed in his studies that in humans the process of coronary collateralisation reduced the severity of myocardial infarction as well as helped maintain the ventricular function. Elsman et al. [19] suggested that there was much difference in the survival rate of the patients with and without collaterals and found that the survival rate is lower in patients without collaterals when compared with subject with well-developed coronary collaterals. Evidence from various studies supported the idea that the presence of coronary collaterals act as a great prognostic indicator during coronary heart disease [63]. It was found that the presence of functional collaterals promotes mortality reduction and reduces myocardial infarct size, which in turn reduces the risk of rupture of papillary muscle and interventricular septum [45].

In normal individuals even if the coronary collaterals are present, it cannot be visualised in angiogram due to its small size. Normal coronary collaterals are microvasculature and act as an alternative source of blood circulation during coronary occlusion when drastic functional and structural changes occur [14]. Fulton [24] explained that the size of normal collaterals in the absence of CAD ranges from 10-200 um and during CAD its diameter increases to $100-800 \mathrm{um}$. The development of stenosis in the epicardial artery causes ischaemia, which in turn produces pressure gradient between the donor and recipient artery and causes formation of collaterals by two processes: angiogenesis and arteriogenesis [60]. Natural coronary collaterals upon stimulation undergo remodelling to large arteri- oles with a calibre increment of 5-10 folds and exhibit tortuosity which distinguish it from other vessels. The expansion of natural collaterals into functional collaterals is known as arteriogenesis, while angiogenesis is the formation of new capillaries from already existing capillaries. Shear stress is the main factor leading to angiogenesis while arteriogenesis occurs without shear stress and factors affecting it are cytokines, monocytes, growth factors and stem cells [13]. Presence of collaterals maintains the viability of myocardium for longer period by extending the time buffer for successful reperfusion until the reperfusion of the occluded artery takes place by the process of thrombolysis or primary percutaneous interventions [10]. Stimulation of these coronary collaterals is the only procedure that can be done in patients having contra-indication to percutaneous intervention and bypass grafting.

\section{CLASSIFICATION OF COLLATERALS}

The collaterals include microvascular collaterals and native collaterals. Micro-vascular collaterals are arteriole-arteriole anastomoses between systemic arteries. Native collaterals are those present in healthy tissues that are free from arterial obstruction and function in normal physiological condition [79]. Anastomoses between left and right coronary arteries through native collaterals are seen abundantly during foetal life but their number decreases during the first year [16]. These channels which appear in adults range from 40-200 um in diameter and reach up the diameter of 800 um during coronary artery occlusion. The length of these coronary collaterals ranges from $1-2 \mathrm{~cm}$ to $4-5 \mathrm{~cm}$ [7]. Coronary collaterals are frequently formed in the following areas: the anterior aspect of the right ventricle, the apex of the heart, the posterior aspect of the left ventricle, and the crux of interatrial and interventricular groove [59]. Native collaterals provide an alternate source of blood during coronary occlusion and undergo drastic changes at the time of occlusion [14].

Wustmann et al. [74] classified the collateral anastomoses into homocollaterals anastomoses and intercoronary anastomoses. Homocoronary anastomoses occur everywhere except in the subepicardial layer of the heart and intercoronary anastomoses are more in subepicardial layer. Homocoronary collaterals are anastomoses between the parts of the same coronary artery and intercoronary collaterals are anastomoses between right and left coronary arteries. In his study collaterals were also classified into good and bad collaterals. 
Table 1. Presence and extent of collateral supplying the occluded vessels from the homo coronary and hetero coronary collaterals are graded under a four-point scale under the Rentrop classification

\begin{tabular}{lc}
\hline Grades of collaterals & Classification \\
\hline Grade 0 & No filling of collateral vessels \\
Grade 1 & $\begin{array}{c}\text { Filling of collateral vessels without any } \\
\text { epicardial filling of target artery } \\
\text { Partial epicardial filling by collateral } \\
\text { vessel of target artery }\end{array}$ \\
Grade 2 & $\begin{array}{c}\text { Complete filling of main epicardial recipient } \\
\text { artery by collateral vessels of target artery }\end{array}$ \\
\hline
\end{tabular}

Good collaterals are considered as the collaterals that can maintain the left ventricular function and bad were related with impaired ventricular function. The good collaterals with more than 100 um in diameter have protective role in maintaining the ventricular function. And these functional collaterals are formed from pre-existing arterioles by the process of arteriogenesis

\section{METHODS OF EVALUATION OF COLLATERALS}

There are various methods for assessment of coronary collateral function, which includes both invasive and non-invasive technique. The various methods of grading collaterals through invasive techniques are: 1. Grading of coronary collaterals was first described by Rentrop et al. [57] and was done by balloon occlusion of contralateral coronary artery. Collaterals were graded into grade 0, grade 1 , grade 2 , and grade 3 (Table 1). Collateral graded under a four-point scale under the Rentrop classification (Figs. 1, 2) [57].

This method has limitations as it mainly depends on the pressure and flow of contrast during injection angiography. Rentrop et al. [58] documented the relation between the severity of stenosis and development of collaterals and found that collaterals increased in patients having beyond $70 \%$ occlusion. The shortfalls of the angiographic study were pointed out by Helfant et al. [26]. In their study on patients with $75 \%$ of stenosis, those with collaterals and without collaterals were compared in terms of their ventricular function. And the conclusion was made that the patients with more collaterals showed ventricular contraction abnormalities. The difference between the results of this and the previous studies was attributed to two reasons: the population selected by the earlier

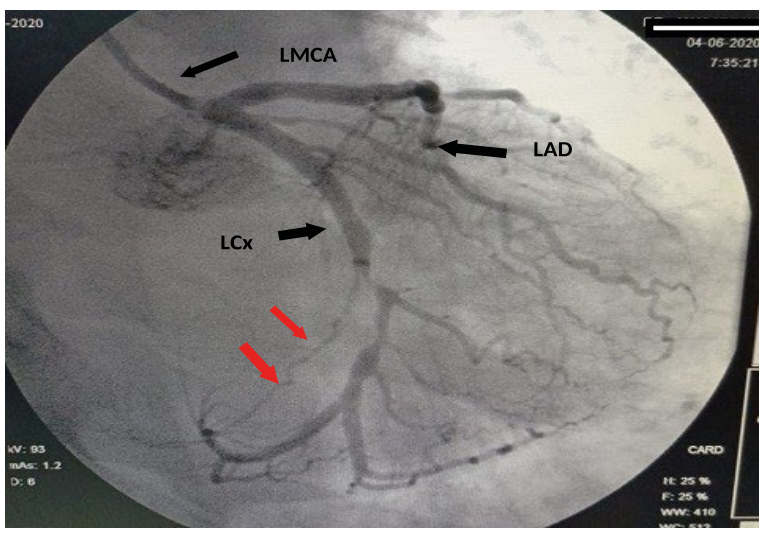

Figure 1. Coronary angiogram - complete filling of distally occluded circumflex artery via homo collateral channels (red arrows — grade 2 collateral); LAD — left anterior descending artery; LMCA — left main coronary artery; LCx — left circumflex artery.

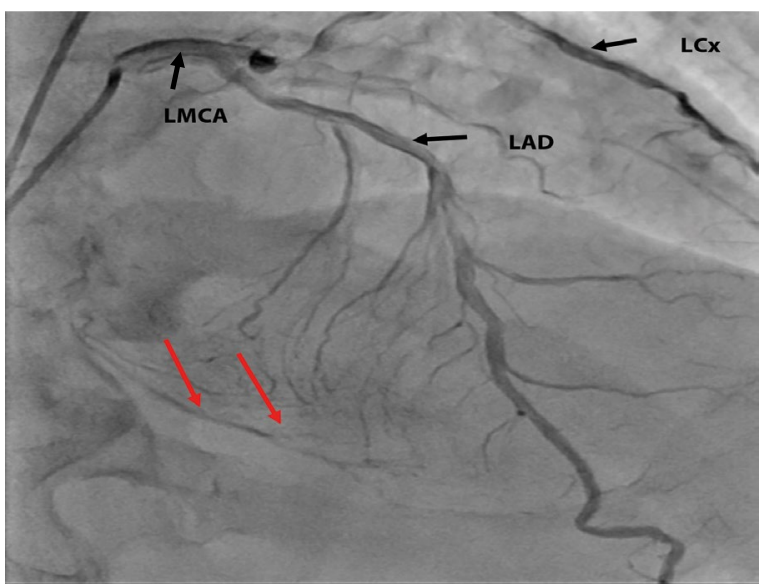

Figure 2. Coronary angiogram with injection of radiographic contrast into left main coronary artery (LMCA) (red arrow - grade 1 collaterals); LAD — left anterior descending artery; LCx — left circumflex artery.

Table 2. Collateral score evaluated according to the presence of connection between donor and recipient artery

\begin{tabular}{lc}
\hline Collateral grades & Classification \\
\hline CCO & $\begin{array}{c}\text { No continuous connection between the } \\
\text { recipient and the donor artery } \\
\text { CC1 } \\
\text { CC2 }\end{array}$ \\
& $\begin{array}{c}\text { Continuous thread-like connection } \\
\text { the course of collateral }\end{array}$ \\
\hline
\end{tabular}

CC - collateral connection

study had $90 \%$ of the occlusion and the samples selected were not homogenous in all respects.

2. The more recently described angiographic classification, collateral connection (CC) grades, is based on the size of the collaterals (Table 2) [73]. 
3. Measuring collateral flow index (CFI). There are two methods available, one is Doppler velocity measurement and the other is pressure measurement. The use of Doppler wire to access the effect of occlusion was demonstrated first by Morton Kern's lab. But while assigning the phasic flow of collaterals it showed higher magnitude in systole which differed from diastole [55].

4. Measuring the collateral function using intracoronary electrocardiogram (ECG) lead where coronary pressure guide wire is used as ECG lead and ST segment elevation $>0.1 \mathrm{mV}$ is used as threshold level to detect the ischaemia [44].

\section{VARIABILITY IN FORMATION OF COLLATERALS}

Great variability exists in the formation of collaterals in patient with similar severity of coronary heart disease. This variability depends mainly on the various factors and has individual differences [39]. Studies show that various independent variables affect the collateralisation. This includes factors like morphology of coronary artery, location of the lesion, coronary dominance, various biochemical factors, age, sex, and duration of the occlusion [42]. Collateral vessel formation is also seen impaired in metabolic syndromes such as diabetes mellitus, hyperlipidaemia and hypertension [1].

\section{EFFECT OF THE MORPHOLOGY OF CORONARY ARTERY ON THE FORMATION OF COLLATERALS}

The concept of collateral development is based on careful anatomical studies done by Jamies [33] and Baroldi et al. [7]. There are two main coronary arteries that supply oxygenated blood to the myocardium. These are left main coronary artery (LMCA) and right coronary artery (RCA). LMCA originates from the left sinus of Valsalva while the RCA originates from the right sinus of Vasalva [47]. The difference in the diameter of the ostia and their location in the sinus of Vasalva affect the amount of coronary blood flow. Usually LMCA bifurcates to left anterior descending artery and left circumflex artery. Left anterior descending artery gives septal branch and 1-3 obtuse marginal branches while RCA gives only one large acute marginal branch [65]. Studies shows that anatomic variation in orifice, courses, branching pattern and abnormalities of coronary artery, presence of myocardial bridges and coronary fistula affects the haemodynamic characteristics of the artery [4]. Various morphological changes have been noticed in studies conducted on coronary arteries. The common trunk of left coronary artery is described as $15 \mathrm{~mm}$ in length. Long common trunk is present in $11.5 \%$ to $18 \%$ of cases and the short trunk, which is less than $5 \mathrm{~cm}$, is considered as important risk factor for coronary artery sclerosis. Banchi [6] in 1904 found in his studies that the common trunk trifurcates in $25 \%$ of cases. Frescura et al. [22] in 1946 found in his studies that the presence of third coronary artery varies between $33 \%$ and $51 \%$ of cases. Absence of LMCA is common anomaly that can be detected in $0.4-8 \%$ of the population [69]. The difference in the diameter and branching pattern of the artery influences the amount of blood flow, which in turn affects the collateralisation.

\section{EFFECT OF MYOCARDIAL BRIDGES ON COLLATERAL FORMATION}

Myocardial bridges are myocardial fibres that spread over a segment or branch of a coronary artery. The presence of myocardial bridges causes a typical angina if it is long and deep [34]. Myocardial bridges occur in $60 \%$ of normal hearts. The length of the bridges ranges from $9.69 \mathrm{~mm}$ to $50 \mathrm{~mm}$. The myocardial bridge usually occurs around the right marginal branch and posterior interventricular branch of RCA. It is very important when present in the proximal part of the artery. It causes compression during systole and the severity ranges from tachyarrhythmia and myocardial infarction [18].

It is now accepted that coronary obstruction is an important stimulus that promotes the development of coronary collateral network. Proximal location of the lesion is found to be an independent variable determining the collateral development other than the severity of the angina pectoris [23]. The percentage of diameter and coronary artery narrowing is also an independent predictor of collateral channel.

\section{CORONARY DOMINANCE}

Identification of coronary dominance has been found to be important in the interpretation of myocardial ischaemia. Angiographic records of 2029 consecutive patients by Ajayi et al. [3] showed that right dominance influences much excellent collateralisation between the coronary arteries. Hence, coronary dominance can be considered as an important factor determining the collateral formation in CAD. In patients 
with left coronary dominance, the RCA will be smaller, which have a disastrous consequence, as the potential for rapid development and reopening of collateral vessel is likely diminished. Left dominance seems to be associated with higher mortality due to acute infarction and higher incidence of atherosclerosis [11].

\section{MECHANICAL AND CHEMICAL FACTORS AFFECTING COLLATERAL FORMATION}

\section{Shear stress}

Increase in shear stress affects the collateral growth. The difference in pressure gradient during occlusion between the occluded artery and the feeding artery of the collaterals acts as a driving force to produce shear stress. The endothelial cells sense the change in this shear stress through the mechanoreceptors present in the endothelial glycocalyx. Cell adhesion is regulated by certain molecules such as cell adhesion molecule and vascular cell adhesion molecule which facilitates the adhesion of mononuclear cells in the circulatory system and mononuclear cells which induce angiogenesis [32]. Angiogenesis is the process of formation of capillaries as a result of fluid shear stress which can only partly contribute to tissue perfusion; the conversion of these capillaries into functional collateral is termed as arteriogenesis [2].

Patel et al. [52] suggested those collaterals can be formed without shear stress and ischaemia can cause collateral growth which is mainly mediated by stem cells, chemical and genetic factors.

\section{Effect of exercise on shear stress}

Exercise was found to have a positive impact on collateral growth. Nickolay et al. [49] in his studies found that exercise increases the myocardial demand, which increases coronary flow and acts as a driving force for arteriogenesis, which helps in formation of collaterals in patients with stable CAD. However, exercise would also exacerbate ischaemia during coronary stenosis; hence, shear stress was found to have minimal effect on collateralisation [45].

\section{GRANULOCYTE MACROPHAGE COLONY STIMULATING FACTOR}

Granulocyte macrophage colony stimulating factor was introduced in a randomised placebo-controlled trial to improve collateralisation and it was noticed that it in turn caused rupture of the plaque [50].

\section{Neutrophil-lymphocyte ratio}

Neutrophil-lymphocyte ratio was considered as a marker of inflammatory cardiovascular diseases [29]. Neutrophils are involved in inflammatory responses and lymphocytes play an important role in immune responses and there exist a relation between immune responses and infarction aggravation. A decrease in the lymphocyte count is associated with a poor outcome in acute coronary syndrome [51].

\section{Monocytes}

The arterial remodelling was induced by the circulating mononuclear cells, monocytes. The monocytes secrete metalloproteinases which help in arterial remodelling. Hence, it was noticed that factors such as monocyte chemoattractant protein-1 (MCP-1) and platelet-derived growth factors can induce the level of collateralisation [28]. Monocyte adhesion is associated with arteriogenesis. Shear stress caused by the change in the blood flow in the occluded and feeding artery causes activation of the endothelial cells, which increases the adhesion of monocytes. This process is supported by vascular endothelial growth factor (VEGF-A); it acts on the endothelial cells which cause an increase in the adhesion of monocytes by activation of cellular adhesion molecule [15]. Thus, VEGF-A has been shown as an inducer of collateralisation. The differences in the genetic makeup in forming monocytes also depend on formation of collaterals during CAD [40].

\section{Eosinophils}

According to studies of Toor et al. [67] eosinophils are new biomarkers for risk stratification in patients with CAD. Eosinophil count $>0.12 \times 100$ can predict abundant coronary collateral circulation with $72.5 \%$ probability and $58.4 \%$ specificity. According to Verdoia et al. [68] the number of collaterals is higher in patients with high level of eosinophils. Wang et al. [72] investigated the relation between the eosinophil count and collateral development and found that the number of eosinophils is high in people with high level of collateral development.

\section{EFFECT OF VEGF ON THE PROCESS OF ARTERIOGENESIS}

Studies show that by increasing the level of VEGF-A by recombinant gene coding for VEGF-A, a great improvement in the formation of collaterals is observed [41]. The growth factors released during angiogenesis are induced by VEGF mRNA [17]. 
Impaired VEGF-A in diabetes mellitus causes low collateralisation [70]. VEGF-A induces monocyte migration, which is disturbed in diabetes mellitus [71]. Kranz et al. [38] studied on the level of VEGF-A in the blood serum during acute myocardial infarction with the help of immuno-radiometric assay. The level of VEGF-A in the serum was measured in healthy individuals and in patients with unstable angina pectoris. This was also compared with the level of VEGF-A in the blood of sub-coronary sinus in patient with sub-acute myocardial infarction. The level of VEGF-A in healthy controls was $98(75-137) \mathrm{pg} / \mathrm{mL}$ and in patients with unstable angina ii was 116 (57-140) $\mathrm{pg} / \mathrm{mL}$. The level of VEGF-A taken from the coronary sinus was noted as $61(43-83) \mathrm{pg} / \mathrm{mL}$, which shows that the main source of VEGF in the serum is not the infracted myocardium. Hung et al. [30] assessed the diagnostic value of serum VEGF-A for distinguishing acute coronary syndrome from stable angina in 248 CAD patients and 48 healthy subjects. They concluded that the level of VEGF-A was higher in CAD patients compared to those with stable angina pectoris.

\section{IMPAIRED COLLATERALS AND CARDIAC RISK FACTORS}

\section{Gender and age}

Aging reduces the arterial remodelling, which in turn decreases collateral-depended flow that acts as a recovery for acute obstruction in coronary arteries [21]. Aging compromises mobilisation and homing of stem cells and inflammatory cells, which induces collateral remodelling. Aging reduces the stem cell capacity to secrete cytokines which help in remodelling of collaterals [75].

Studies shows that gender is not related to the collateralisation, but still some studies shows that collateralisation is more in females with multi-vessel disease. Chigogidze et al. [12] conducted a review of all articles of the last 10 years and found that no research was on gender differences in collateral formation and circulation. About $96 \%$ of the female affected by coronary heart disease are above the age of 50 and post-menopausal, which may lead to the inference that oestrogen directly modulates angiogenesis by its effect on the endothelial cells [48].

The protection against cardiovascular disease in women during reproductive age is believed to be related at least in part to oestrogen, since endogenous levels of oestrogen and the expression of oestrogen receptors differ considerably between sexes. Oestro- gen mediates its cardio protective actions by increasing angiogenesis and vasodilation and decreasing reactive oxygen species, oxidative stress, and fibrosis. Through these mechanisms, oestradiol limits cardiac remodelling and attenuates heart hypertrophy [31].

\section{Smoking and alcohol}

Koerselman et al. [36] conducted a cross-sectional study on the effect of smoking and alcohol on the coronary collaterals and found association between the lifestyle behaviours and the level of collateralisation.

\section{EFFECT OF METABOLIC SYNDROMES SUCH AS DIABETES MELLITUS AND HYPERTENSION ON COLLATERALISATION}

Patients with metabolic syndrome had increased risk of cardiovascular mortality and morbidity. The metabolic syndrome which is accepted as a cardiovascular risk factor includes impaired glucose metabolism, elevated blood pressure, dyslipidaemia and central obesity. The metabolic syndrome is highly prevalent in patients with vascular diseases [20].

\section{Hypertension}

Koreselman et al. [35] found in his studies that high blood pressure with coronary obstruction causes impaired collateral formation. Studies showed that diastolic prolongation is also associated with improved collateral growth. Patel et al. [53] found that patients with heart rate of 50 beats develop more collaterals compared to patients with 60 beats per minutes. Pressure increases fluid shear stress on the endothelial cells, which in turn increases the level of collateralisation or remodelling pressure [66].

\section{Diabetes mellitus}

The mortality in CAD is found to be higher in diabetic patients and the adverse effect of diabetes mellitus on prognosis of coronary artery is well known [9]. Great difference in recruitment of coronary collaterals in diabetic and non-diabetic patients have been shown in angiographic studies. The influence of diabetes mellitus on CAD is in controversy. It is mainly based on angiographic study, as angiographic method is considered as semiquantitative method for assessing the collateral formation in diabetes mellitus [62]. Diabetes mellitus causes endothelial dysfunction and structural changes in microcirculation, which negatively influence the development of collaterals [61]. The difference in 
the collateral development in the diabetic patients is due to the impaired endothelial function in diabetes [70]. Microvascular resistance is higher in diabetic patients and this resistance determines the bloods flow distal to the occluded vessels, which results in impaired collateral recruitment [54]. Kornowski [37] showed that collateral grade is associated with hyperlipidaemia and is negatively associated with diabetes mellitus. Studies based on CFI show that collateral formation is independent of diabetic mellitus and the degree of collaterals depends on the coronary artery stenosis. It was found that collateral score is similar in patients with duration of stenosis less than 5 years. And the difference is showed only in patients with duration between 5 and 10 and more than 10 years. Hyperinsulinaemia brings both functional and structural changes in blood vessels. Functional changes are through nitric oxide by receptor-mediated resistance, which maintains the vasodilation, and structural changes occur by proatherogenic responses mediated by MAP kinase pathway, causing significant changes over a period of time [64]. Earlier studies suggested that diabetic patients had poor collateral formation [43], but recent studies have shown that it is independent of diabetes mellitus and the degree of collateral formation is only depended on the degree of coronary artery stenosis [46]. Zbinden et al. [77] studied 200 patients of which 100 were diabetic and 100 non-diabetic, of this 174 had stenosis and 26 were angiographically normal. Doppler guide wire was used to calculate the coronary flow velocity. The patients were homogenous in all respects and this study found no difference in the coronary flow index between the diabetic and non-diabetic patients.

Pohl et al. [56] conducted a study in 450 patients who underwent angioplasty and collateral flow was measured using Rentrop classification. Also, CFI was measured using sensor-tipped percutaneous transluminal coronary angioplasty guide wire. Multivariate analysis of factors such as gender, age and various cardiovascular risk factors was performed and found that myocardial ischaemia and coronary lesion severity are the only factors that determine the collateral flow. Ansari Anvil et al. [5] studied on the clinical determinants of collateral formation. Medical history was correlated with the angiographic evidence of collateral blood flow and there was no relation between the grades of collateral formation and the risk factors. Still, there are few studies that reported the set of variables such as age, gender, smoking status, history of type 2 diabetes mellitus, hypertension, hyperlipidaemia, alcohol conceptions as predictors of collateral circulation.

\section{THERAPEUTIC PROMOTION OF COLLATERALS}

\section{Stem cells therapy}

Stem cells therapy with vascular progenitor for vascular endothelial cells stimulates collateral in rat models. When these stem cells are engrafted into the blood vessels it was found better than pluripotent stem cells and mesenchymal cells in preclinical studies [76]. If the preclinical model mimics all the risk factors that inhibit the growth of collaterals, it would make an effective therapeutic strategy. If we consider these factors, the young healthy animals are not any way similar to the aged human with lots of risk factors. Thus, the administration of vascular endothelial factors given directly into the cardiac tissue doesn't cause any useful clinical impact. It has been found that arteriogenic therapies by growth factors showed subsequent development of collaterals in patients with stable angina, but in some patients it progressed to unstable angina [78].

\section{CONCLUSIONS}

Collateral formation and its remodelling depends on multiple factors, which leads to variability in the quality and function of collaterals during CAD. The effect of various demographic, morphological and cardiac risk factors on formation of coronary collaterals remains as an inconclusive issue. Therapeutic promotion of these collaterals is essential as these are alternative sources of blood flow, which results in long term mortality reduction. Further studies should be conducted on various factors affecting the collateral formation in obstructive coronary diseases to open new strategies for therapeutic promotion of collateralisation. Aiding and promoting collateralisation can help overcome the severe limitation of therapies available in cardiovascular diseases treatments and also can open new horizons in the treatment of CAD. A complete knowledge about various factors causing variability in the formation of these collaterals give way for more effective methods of understanding and employing therapeutic strategies.

\section{Acknowledgements}

The author wish to acknowledge the Cardiology Department of Palakkad Institute of Medical Sciences and Research Centre for sharing the patient data with 
their requisite consent and conducting further study on the factors affecting coronary collateral formation.

Government Medical College (Institute of Integrated Medical Sciences) for granting IEC clearance for the research project on coronary collaterals.

\section{Conflict of interest: None declared}

\section{REFERENCES}

1. Abaci A, Oğuzhan A, Kahraman S, et al. Effect of diabetes mellitus on formation of coronary collateral vessels. Circulation. 1999; 99(17): 2239-2242, doi: 10.1161/01. cir.99.17.2239, indexed in Pubmed: 10226087.

2. Adair TH, Montani JP. Angiogenesis. Morgan \& Claypool Life Sciences, San Rafael, CA 2010.

3. Ajayi NO, Vanker EA, Satyapal KS. Coronary artery dominance dependent collateral development in the human heart. Folia Morphol. 2017; 76(2): 191-196, doi: 10.5603/ FM.a2016.0051, indexed in Pubmed: 27665958.

4. Altin C, Kanyilmaz S, Koc S, et al. Coronary anatomy, anatomic variations and anomalies: a retrospective coronary angiography study. Singapore Med J. 2015; 56(6): 339-345, doi: 10.11622/smedj.2014193, indexed in Pubmed: 25502334.

5. Ansari Aval Z, Foroughi M. Impacts of established cardiovascular risk factors on the development of collateral circulation in chronic total occlusion of coronary arteries. Dis Markers. 2014; 1(3): 1011-1014.

6. Banchi A .Morfologia della arteriae coronariae cordis.Arch Ital.Anat Embriol.1904;3:87-164

7. Baroldi G, Mantero O, Scomazzoni G. The collaterals of the coronary arteries in normal and pathologic hearts. Circ Res. 1956; 4(2): 223-229, doi: 10.1161/01.res.4.2.223, indexed in Pubmed: 13293825.

8. Benjamin EJ, Blaha MJ, Chiuve SE, et al. Heart Disease and Stroke Statistics-2017 Update: A Report From the American Heart Association. Circulation. 2017; 135(10): 146-603, doi: 10.1161/CIR.0000000000000485, indexed in Pubmed: 28122885.

9. Buschmann EE, Brix M, Li L, et al. Adaptation of external counterpulsation based on individual shear rate therapy improves endothelial function and claudication distance in peripheral artery disease. Vasa. 2016; 45(4): 317-324, doi: 10.1024/03011526/a000544, indexed in Pubmed: 27428501.

10. Charney R, Cohen M. The role of the coronary collateral circulation in limiting myocardial ischemia and infarct size. Am Heart J. 1993; 126(4): 937-945, doi: 10.1016/00028703(93)90710-q, indexed in Pubmed: 8213453.

11. Chien S. Mechanotransduction and Endothelial cell Homeostasis: The wisdom of cells. Am J Physiol Heart Circ Physiol. 2007; 292(3): H1209-H1224, doi: 10.1152/ ajpheart.01047.2006, indexed in Pubmed: 17098825.

12. Chigogidze M, Sharashidze N, Paghava Z. Gender differences in coronary collateral Circulation during acute and stable ischemic heart diseases. Translational and Clinical Medicine. Georgian Med J Clin Med. 2018; 3: 25-31.

13. Chilian WM, Mass HJ, Williams SE, et al. Microvascular occlusions promote coronary collateral growth. Am J Physiol Heart Circ Physiol. 1990; 258(4): H1103-H1111, doi: 10.1152/ajpheart.1990.258.4.h1103.
14. Chilian WM, Penn MS, Pung YF, et al. Coronary collateral growth: back to the future. J Mol Cell Cardiol. 2012; 52(4): 905-911, doi: 10.1016/j.yjmcc.2011.12.006, indexed in Pubmed: 22210280.

15. Clauss $M$, Weich $H$, Breier $G$, et al. The vascular endothelial growth factor receptor Flt-1 mediates biological activities. Implications for a functional role of placenta growth factor in monocyte activation and chemotaxis. J Biol Chem. 1996; 271(30): 17629-17634, doi: 10.1074/jbc.271.30.17629, indexed in Pubmed: 8663424.

16. Cohen M, Rentrop KP. Limitation of myocardial ischemia by collateral circulation during sudden controlled coronary artery occlusion in human subjects: a prospective study. Circulation. 1986; 74(3): 469-476, doi: 10.1161/01. cir.74.3.469, indexed in Pubmed: 2943529.

17. Conway E, Collen D, Carmeliet P. Molecular mechanisms of blood vessel growth. Cardiovasc Res. 2001; 49(3): 507-521, doi: 10.1016/s0008-6363(00)00281-9.

18. Dursun I, Bahcivan M, Durna K, et al. Treatment strategies in myocardial bridging: a case report. Cardiovasc Revasc Med. 2006; 7(3): 195-198, doi: 10.1016/j.carrev.2006.02.003, indexed in Pubmed: 16945830.

19. Elsman P, van ,t Hof AWJ, de Boer MJ, et al. Role of collateral circulation in the acute phase of ST-segment-elevation myocardial infarction treated with primary coronary intervention. Eur Heart J. 2004; 25(10): 854-858, doi: 10.1016/j. ehj.2004.03.005, indexed in Pubmed: 15140533.

20. Expert Panel on Detection, Evaluation, and Treatment of High Blood Cholesterol in Adults. Executive Summary of The Third Report of The National Cholesterol Education Program (NCEP) Expert Panel on Detection, Evaluation, And Treatment of High Blood Cholesterol In Adults (Adult Treatment Panel III). JAMA. 2001; 285(19): 2486-2497, doi: 10.1001/jama.285.19.2486, indexed in Pubmed: 11368702.

21. Faber JE, Zhang H, Lassance Soares RM. Aging causes collateral rarefaction and increased severity of ischemic injury in multiple tissues. Arterioscler Thromb Vasc Biol. 2011; 31(8): 1748-1756, doi: 10.1161/ATVBAHA.111.227314, indexed in Pubmed: 21617137.

22. Frescura C, Basso C, Thiene G, et al. Anomalous origin of coronary arteries and risk of sudden death: A study based on an autopsy population of congenital heart disease. Hum Pathol. 1998; 29(7): 689-695, doi: 10.1016/s00468177(98)90277-5.

23. Fujita M, Nakae I, Kihara $Y$, et al. Determinants of collateral development in patients with acute myocardial infarction. Clin Cardiol. 1999; 22: 595-599, doi: 10.1002/ clc.4960220911, indexed in Pubmed: 10486700.

24. Fulton WF. Arterial anastomoses in the coronary circulation: I. Anatomical features in normal and diseased hearts demonstrated by stereo arteriography. Scott Med J. 1963; 8: 420-434, doi: 10.1177/003693306300801102, indexed in Pubmed: 14075729.

25. Habib GB, Heibig J, Forman SA, et al. Influence of coronary collateral vessels on myocardial infarct size in humans. Results of phase I thrombolysis in myocardial infarction (TIMI) trial. The TIMI Investigators. Circulation. 1991; 83(3): 739-746, doi: 10.1161/01.cir.83.3.739, indexed in Pubmed: 1900223.

26. Helfant RH, Kemp HG, Gorlin R, et al. Coronary atherosclerosis, coronary collaterals, and their relation to cardiac function. 
Ann Intern Med. 1970; 73(2): 189-193, doi: 10.7326/00034819-73-2-189, indexed in Pubmed: 5454255.

27. Heusch G. Molecular basis of cardioprotection: signal transduction in ischemic pre-, post-, and remote conditioning. Circ Res. 2015; 116(4): 674-699, doi: 10.1161/ CIRCRESAHA.116.305348, indexed in Pubmed: 25677517.

28. Hoefer IE, Van Royen N, Rectenwald JE, et al. Direct evidence for tumor necrosis factor-alpha signalling in arteriogenesis. Circulation. 2002; 105(14): 1639-1641, doi: 10.1161/01.cir.0000014987.32865.8e, indexed in Pubmed: 11940540.

29. Horne BD, Anderson JL, John JM, et al. Which white blood cell subtypes predict increased cardiovascular risk? J Am Coll Cardiol. 2005; 45(10): 1638-1643, doi: 10.1016/j. jacc.2005.02.054, indexed in Pubmed: 15893180.

30. Huang A, Qi X, Cui Y, et al. Serum VEGF: diagnostic value of acute coronary syndrome from stable angina pectoris and prognostic value of coronary artery disease. Cardiol Res Pract. 2020; 2020: 6786302, doi: 10.1155/2020/6786302, indexed in Pubmed: 32411449.

31. lorga A, Cunningham CM, Moazeni S, et al. The protective role of estrogen and estrogen receptors in cardiovascular disease and the controversial use of estrogen therapy. Biol Sex Differ. 2017; 8(1): 33, doi: 10.1186/s13293-017-01528, indexed in Pubmed: 29065927.

32. Ito WD, Arras M, Scholz D, et al. Schaper. Angiogenesis but not collateral growth is associated with Ischemia after femoral artery occlusion. Am J Physiol. 1997; 273(3 Pt. 2): H1255-H1265, doi: 10.1152/ajpheart.1997.273.3.H1255, indexed in Pubmed: 9321814.

33. Jamies TN. Anatomy of the coronary arteries. Paul B. Hoeber, New York 1961.

34. Kayrak M, Ulgen MS, Ergene O, Kozan O. Textbook of Invasive cardiology, 1st ed. Hacettepe University Basımevi, Ankara 2007: 12-19.

35. Koerselman J, de Jaegere PP, Verhaar MC, et al. SMART Study Group. High blood pressure is inversely related with the presence and extent of coronary collaterals. J Hum Hypertens. 2005; 19(10): 809-817, doi: 10.1038/ sj.jhh.1001917, indexed in Pubmed: 16107856.

36. Koerselman J, de Jaegere PP, Verhaar $\mathrm{M}$, et al. Coronary collateral circulation: The effects of smoking and alcohol. Atherosclerosis. 2007; 191(1): 191-198, doi: 10.1016/j. atherosclerosis.2006.03.021, indexed in Pubmed: 16696984.

37. Kornowski R. Collateral formation and clinical variables in obstructive coronary artery disease: the influence of hypercholesterolemia and diabetes mellitus. Coron Artery Dis. 2003; 14(1): 61-64, doi: 10.1097/00019501-20030200000007, indexed in Pubmed: 12629327.

38. Kranz A, Rau G, Kochs M, et al. Elevation of vasculoendothelial growth factor: a serum level following acute Myocardial Infarction. Evidence for its origin and function significance. J Mol Cell Cardiol. 2000; 32(1): 65-72, doi: 10.1006/jmcc.1999.1062, indexed in Pubmed: 10652191.

39. Ladwiniec A, Hoye A. Coronary collaterals little give and take and a few unanswered questions. J Clin Exp Cardiol. 2013; 4(4): 2155-4172, doi: 10.4172/2155$9880.1000 \mathrm{e} 124$.

40. Lazarous DF, Shou M, Scheinowitz M, et al. Comparative effects of basic fibroblast growth factor and vascular endothelial growth factor on coronary collateral development and the arterial response to injury. Circulation. 1996; 94(5): 1074-1082, doi: 10.1161/01.cir.94.5.1074, indexed in Pubmed: 8790049.

41. Lederman RJ, Mendelsohn FO, Anderson RD. Therapeutic angiogenesis with recombinant fibroblast growth factors- 2 for intermittent claudication. Lancet. 2002; 359(9323): 2053-2058, doi: 10.1016/s01406736(02)08937-7, indexed in Pubmed: 12086757.

42. Levin DC. Pathways and functional significance of the coronary collateral circulation. Circulation. 1974; 50(4): 831-837, doi: 10.1161/01.cir.50.4.831, indexed in Pubmed: 4425386.

43. Mather KJ, Steinberg HO, Baron AD. Insulin resistance in the vasculature. J Clin Invest. 2013; 123(3): 1003-1004, doi: 10.1172/JCl67166, indexed in Pubmed: 23454764.

44. Meier B, Rutishauser W. Coronary pacing during percutaneous transluminal coronary angioplasty. Circulation. 1985; 71(3): 557-561, doi: 10.1161/01.cir.71.3.557, indexed in Pubmed: 3156008.

45. Meier P, Gloekler S, de Marchi SF, et al. Myocardial salvage through coronary collateral growth by granulocyte colony-stimulating factor in chronic coronary artery disease: a controlled randomized trial. Circulation. 2009; 120(14): 1355-1363, doi: 10.1161/CIRCULATIONAHA.109.866269, indexed in Pubmed: 19770393.

46. Melidonis A, Tournis S, Kouvaras G, et al. Comparison of coronary collateral circulation in diabetic and nondiabetic patients suffering from coronary artery disease. Clin Cardiol. 1999; 22(7): 465-471, doi: 10.1002/clc.4960220706, indexed in Pubmed: 10410290.

47. Mittal N, Zhou Y, Linares C, et al. Analysis of blood flow in the entire coronary arterial tree. Am J Physiol Heart Circ Physiol. 2005; 289(1): H439-H446, doi: 10.1152/ ajpheart.00730.2004, indexed in Pubmed: 15792992.

48. Mosca L, Appel L, Benjamin EJ, et al. Evidence-based guidelines for cardiovascular disease prevention in women. American Heart Association scientific statement. Arterioscler Thromb Vasc Biol. 2004; 24(3): e29-e50, doi:10.1161/01.ATV.0000114834.85476.81, indexed in Pubmed: 15003974.

49. Nickolay T, Nichols S, Ingle L, et al. Excercise training as a mediators for enhancing coronary collateral circulation: a review of the evidence. Curr Cardiol Rev. 2020; 16(3): 212-220, doi: 10.2174/1573403X15666190819144336, indexed in Pubmed: 31424373.

50. Niebauer J, Hambrecht R, Marburger C, et al. Impact of intensive physical exercise and low-fat diet on collateral vessel formation instable angina pectoris and angiographically confirmed coronary artery disease. Am J Cardiol. 1995; 76(11): 771-775, doi: 10.1016/s00029149(99)80224-0, indexed in Pubmed: 7572652.

51. Ommen SR, Gibbons RJ, Hodge DO, et al. Usefulness of the lymphocyte concentration as a prognostic marker in coronary artery disease. Am J Cardiol. 1997; 79(6): 812-814, doi: 10.1016/s0002-9149(96)00878-8, indexed in Pubmed: 9070569.

52. Patel B, Hopmann P, Desai M, et al. Coronary collateral growth: clinical perspectives and recent insights. Physiologic and Pathologic Angiogenesis - Signaling Mechanisms and Targeted Therapy. 2017; 10: 5772-67164, doi: $10.5772 / 67164$ 
53. Patel SR, Breall JA, Diver DJ, et al. Bradycardia is associated with development of coronary collateral vessels in humans. Coron Artery Dis. 2000; 11(6): 467-472, doi: 10.1097/00019501200009000-00004, indexed in Pubmed: 10966132.

54. Piek JJ, van Liebergen RAM, Koch KT, et al. Comparison of collateral vascular responses in the donor and recipient coronary artery during transient coronary occlusion assessed by intracoronary blood flow velocity analysis in patients. J Am Coll Cardiol. 1997; 29(7): 1528-1535, doi: 10.1016/s0735-1097(97)82538-7.

55. Pijls NH, van Son JA, Kirkeeide RL, et al. Experimental basis of determining maximum coronary, myocardial, and collateral blood flow by pressure measurements for assessing functional stenosis severity before and after percutaneous transluminal coronary angioplasty. Circulation. 1993; 87(4): 1354-1367, doi: 10.1161/01.cir.87.4.1354, indexed in Pubmed: 8462157.

56. Pohl T, Seiler C, Billinger M, et al. Frequency distribution of collateral flow and factors influencing collateral channel development. J Am Coll Cardiol. 2001; 38(7): 1872-1878, doi: 10.1016/s0735-1097(01)01675-8, indexed in Pubmed: 11738287.

57. Rentrop KP, Cohen M, Blanke $H$, et al. Changes in collateral channel filling immediately after controlled coronary artery occlusion by an angioplasty balloon in human subjects. J Am Coll Cardiol. 1985; 5(3): 587-592, doi: 10.1016/ s0735-1097(85)80380-6, indexed in Pubmed: 3156171.

58. Rentrop KP, Feit F, Sherman W, et al. Serial angiographic assessment of coronary artery obstruction and collateral flow in acute myocardial infarction. Report from the second Mount Sinai-New York University Reperfusion Trial. Circulation. 1989; 80(5): 1166-1175, doi: 10.1161/01. cir.80.5.1166, indexed in Pubmed: 2509103.

59. Richard S. Snell. Snell clinical anatomy. 7th ed. Lippincott Williams and Wilkins, Baltimore 2001.

60. Schaper W, Scholz D. Factors regulating arteriogenesis. Arterioscler Thromb Vasc Biol. 2003; 23(7): 1143-1151, doi: 10.1161/01.ATV.0000069625.11230.96, indexed in Pubmed: 12676799.

61. Schofield I, Mlik R, Izzard A, et al. Vascular structural and functional changes in type 2 diabetes mellitus. Circulation. 2002; 106(24): 3037-3043, doi: 10.1161/01. cir.0000041432.80615.a5, indexed in Pubmed: 12473548.

62. Seiler C, Fleisch M, Garachemani A, et al. Coronary collateral quantitation in patients with coronary artery disease using intravascular flow velocity or pressure measurements. J Am Coll Cardiol. 1998; 32(5): 1272-1279, doi: 10.1016/ s0735-1097(98)00384-2, indexed in Pubmed: 9809936.

63. Seiler C, Meier P. Historical aspects and relevance of the human coronary collateral circulation. Curr Cardiol Rev. 2014; 10(1): 2-16, doi: 10.2174/1573403×113099990028, indexed in Pubmed: 23859295.

64. Srinivasan MP, Kamath PK, Bhat NM, et al. Severity of coronary artery disease in type 2 diabetes mellitus: Does the timing matter? Indian Heart J. 2016; 68(2): 158-163, doi: 10.1016/j.ihj.2015.08.004, indexed in Pubmed: 27133324.

65. Standring S, Borley NR, Collins P, Crossman AR, Gatzoulis MA, Chealu J. Grays Anatomy. 40th ed. Churchill Livingstone Elsevier, China 2008.

66. Tayebjee MH, Lip GYH, MacFadyen RJ. Is there an association between hypertension and the development of coronary collateral flow? J Hum Hypertens. 2005; 19: 757-759, doi: 10.1038/sj.jhh.1001906, indexed in Pubmed: 15988537.

67. Toor IS, Jaumdally R, Lip GYH, et al. Eosinophil count predicts mortality following percutaneous coronary intervention. Thromb Res. 2012; 130(4): 607-611, doi: 10.1016/j. thromres.2012.05.033, indexed in Pubmed: 22771073.

68. Verdoia M, Schaffer A, Cassetti E, et al. Absolute eosinophils count and the extent of coronary artery disease: a single centre cohort study. J Thromb Thrombolysis. 2015; 39(4): 459-466, doi: 10.1007/s11239-014-1120-3, indexed in Pubmed: 25079972.

69. Villa ADM, Sammut E, Nair A, et al. Coronary artery anomalies overview: the normal and the abnormal. World J Radiol. 2016; 8(6): 537-555, doi: 10.4329/wjr.v8.i6.537, indexed in Pubmed: 27358682.

70. Walttenberger J. Impaired collateral vessel development in diabetes: potential cellular mechanisms and therapeutic implications. Cardiovasc Res. 2001; 49(3): 554-560, doi: 10.1016/ s0008-6363(00)00228-5, indexed in Pubmed: 11166268.

71. Walttenberger J, Lange J, Kranz A. Vasculoendothelial factors-A-Induced chemotaxis of monocytes is attenuated in patients with diabetes mellitus: A potential predictors for the individual capacity to develop collaterals. Circulation. 2000; 102(2): 185-190, doi: 10.1161/01.cir.102.2.185, indexed in Pubmed: 10889129.

72. Wang J, Li Q, Li Sj, et al. Relationship of coronary collateral circulation with eosinophils in patients with unstable angina pectoris. Clin Interv Aging. 2016; 11: 105-110, doi: 10.2147/CIA.S95363, indexed in Pubmed: 26889082.

73. Werner GS, Ferrari M, Heinke $S$, et al. Angiographic assessment of collateral connections in comparison with invasively determined collateral function in chronic coronary occlusions. Circulation. 2003; 107(15): 1972-1977, doi: 10.1161/01. CIR.0000061953.72662.3A, indexed in Pubmed: 12665484.

74. Wustmann K, Zbinden S, Windecker S, et al. Is there functional collateral flow during vascular occlusion in angiographically normal coronary arteries? Circulation. 2003; 107(17): 2213-2220, doi: 10.1161/01.CIR.0000066321.03474.DA, indexed in Pubmed: 12707241.

75. Xin $\mathrm{Y}$, Wang $\mathrm{YM}$, Zhang $\mathrm{H}$, et al. Aging adversely impacts biological properties of human bone marrow-derived mesenchymal stem cells: implications for tissue engineering heart valve construction. Artif Organs. 2010; 34(3): 215-222, doi: 10.1111/j.1525-1594.2009.00824.x, indexed in Pubmed: 19392880.

76. Yin L, Ohanyan V, Pung YF, et al. Induction of vascular progenitor cells from endothelial cells stimulates coronary collateral growth. Circ Res. 2012; 110(2): 241-252, doi: 10.1161/ CIRCRESAHA.111.250126, indexed in Pubmed: 22095729.

77. Zbinden $R$, Zbinden $S$, Billinger $M$. Influence of diabetes mellitus on coronary collateral flow: an answer to an old controversy. Heart. 2005; 91(10): 1289-1293, doi: 10.1136/hrt.2004.041236, indexed in Pubmed: 16162618.

78. Zimarino $M, D^{\prime}$ Andreamatteo $M$, Waksman $R$, et al. The dynamics of the coronary collateral circulation. Nat Rev Cardiol. 2014; 11(4): 191-197, doi: 10.1038/nrcardio.2013.207, indexed in Pubmed: 24395049.

79. Zoll PM, Wessler S, Schlesinger MJ. Interarterial coronary anastomoses in the human heart, with particular reference to anemia and relative cardiac anoxia. Circulation. 1951; 4(6): 797-815, doi: 10.1161/01.cir.4.6.797, indexed in Pubmed: 14879489. 